\title{
Biblijna kosmologia Jana Kochanowskiego. Ciała niebieskie w „Psałterzu Dawid owym" na tle XVI-wiecznych przekładów Biblii
}

Agata Starownik

Uniwersytet Warszawski

a.starownik@al.uw.edu.pl (1) https://orcid.org/0000-0002-2676-4995

Psałterz Dawidów Jana Kochanowskiego powstawał co najmniej od roku 1571, a po raz pierwszy ukazał się drukiem w krakowskiej Drukarni Łazarzowej w $1579^{1}$. W tym samym roku poeta wydał u Andrzeja Piotrkowczyka łaciński przekład Fenomenów, greckiego poematu astronomicznego Aratosa, zatytułowany M. T. Ciceronis Aratus ad Graecum exemplar expensus \& locis mancis restitutus ${ }^{2}$. Przez całe życie pracował też nad jego polską parafrazą, opublikowaną już po śmierci autora ${ }^{3}$. Prace na bazie Aratosa i Biblii nie tylko wieńczą jego pasje translatorsko-poetyckie, lecz także dają pojęcie o jego wiedzy astronomicznej. To w nich bowiem znalazło się najwięcej odniesień do ciał niebieskich w twórczości Kochanowskiego. Jak nietrudno się domyślić, obraz kosmosu wyrasta w niej z tradycji starożytności zarówno grecko-rzymskiej, jak i judeochrześcijańskiej.

Odniesienia astronomiczne w Psałterzu Dawidowym koncentrują się wokół budowy wszechświata, najważniejszych ciał niebieskich: słońca

1 P. Buchwald-Pelcowa, Wstęp, [w:] Psałterz Dawidów przekładania Jana Kochanowskiego, Warszawa 1985, s. I; E. Buszewicz, Psałterz Dawidów, [w:] Jan Kochanowski, pod red. A. Gorzkowskiego, Kraków 2001, s. 18; J. Pelc, Kochanowski. Szczyt renesansu w literaturze polskiej, Warszawa 2001, s. 111, 126, 481.

2 J. Axer, „Aratus”- miejsce poematu w twórczości Kochanowskiego, [w:] Jan Kochanowski i epoka renesansu. W 450 rocznice urodzin poety. 1530-1980, red. T. Michałowska, Warszawa 1984, s. 160; J. Pelc, Kochanowski. Szczyt renesansu w literaturze polskiej, dz. cyt., s. 127, 481.

3 J. Axer, „Aratus” - miejsce poematu w twórczości Kochanowskiego, dz. cyt., s. 160. 
i księżyca (w dalszej kolejności też gwiazd) oraz ich ruchu po niebie, wyznaczanego przez nie kosmicznego ładu i pochwały harmonijnego stworzenia oraz jego Twórcy. Z porządkiem Jego dzieła wiążą się odwołania do rytmu czasu i podziału przestrzeni, w dużej mierze określanych przez obiekty astronomiczne. W niniejszym tekście omówione zostaną jedynie wybrane motywy opisujące czas i przestrzeń - pełny obraz ciał niebieskich to temat na znacznie obszerniejsze opracowanie.

Według badaczy poeta interesuje się przyrodą nie tyle dla niej samej, ile w imię humanistycznych ideałów. W drugiej połowie XVI wieku stała się ona bowiem ważnym tematem humanistycznej refleksji ${ }^{4}$. Twórca nie zasłynął jednak z plastycznych, zmysłowych opisów natury odwołujących się do wyobraźni. Uważa się go za „daltonistę” niewrażliwego na barwy ${ }^{5}$, który tworzył opisy raczej pojęciowe ${ }^{6}$, ewentualnie zorientowane wokół gier świateł - czyli tylko dwóch sfer: jasnej i ciemnej - niż bogactwa kolorów ${ }^{7}$. Kochanowski nie troszczy się zbytnio o realizm, sensualność, pobudzanie wyobraźni czy szczegóły pejzażu, flory czy fauny. Brak mu zacięcia przyrodoznawczego. Widzi przyrodę przez pryzmat uczuć i refleksji, które budzi ona w człowieku ${ }^{8}$, przez pryzmat intelektu i jej literackich opisów. Opiewa ją za pomocą finezyjnych nawiązań filologicznych, tradycyjnych motywów i symboliki. Naśladuje nie naturę, ale sztukę, która już przetworzyła naturę, jest zatem bogatsza i bliższa ideału ${ }^{9}$.

4 J. Sokolski, „Natura lubi się ukrywać”. Historia naturalis - magia naturalis - philosophia naturalis w Europie wczesnowożytnej, [w:] Człowiek wobec natury - humanizm wobec nauk przyrodniczych, red. J. Sokolski, Warszawa 2010, s. 27-28.

5 S. Dobrzycki, Przyroda w literaturze polskiej w epoce odrodzenia (dokończenie), „Pamiętnik Literacki” 5 (1906) nr 1-4, s. 130; M. Mejor, Historia naturalna w dziełach polsko-łacińskich poetów humanistycznych. Zarys problemu, [w:] Człowiek wobec natury..., dz. cyt., s. 64; W. Weintraub, Rzecz czarnoleska, Kraków 1977, s. 158.

6 W. Weintraub, Rzecz czarnoleska, dz. cyt., s. 152-153.

7 Tamże, s. 156-157.

8 B. Chlebowski, Poezja polska w wieku XVI, [w:] Dzieje literatury pięknej w Polsce, cz. 1, opr. S. Tarnowski et al., Kraków 1918, s. 216; S. Dobrzycki, Przyroda w literaturze polskiej w epoce odrodzenia (dokończenie), dz. cyt., s. 136.

9 M. Mejor, Historia naturalna w dziełach polsko-łacińskich poetów humanistycznych. Zarys problemu, dz. cyt., s. 64-68; E. Ostrowska, O języku opisów przyrody w pieśniach, „Język Polski” 1973 nr 1, s. 1-5. 
Kochanowski czyta księgę przyrody przez pryzmat przeżyć, myśli, twórczości człowieka. W pierwszej kolejności pozostaje badaczem nie dzieła stworzenia, ale literatury - dzieła ludzkiego, z którym wchodzi w artystyczny dialog, jak przystało humaniście i poecie uczonemu. Dlatego w refleksji nad ciałami niebieskimi w Psałterzu nie sposób pominąć tekstu biblijnego leżącego u jego podstaw. Warto w niej uwzględnić inne staropolskie przekłady psalmów - nie tylko poetyckie, lecz także prozatorskie, tworzone na użytek poszczególnych wyznań. Jakie wizje kosmosu się z nich wyłaniają? Czy znacząco się one różnią? Jak się mają do wizji Kochanowskiego?

Uwzględnienie przekładów kanonicznych w odczytaniu treści astronomicznych Psałterza Dawidowego jest ważne ze względu na dwie najważniejsze cechy obrazu ciał niebieskich u Kochanowskiego: wspomnianej już zależności od wzorców literackich oraz neoplatońskiego wydźwięku jego opisu kosmosu. Fizyczne niebo i jego mieszkańcy świadczą o doskonałości harmonijnego stworzenia. Zgodnie z ówczesnym modelem wszechświata stanowią istotną część Bożego dzieła, pośredniczącą między ziemią (sferą ludzką) a niebem (metafizyczną siedzibą Najwyższego). Co więcej, zachwyt pięknem przyrody to jeden z najważniejszych elementów religijności wyrażonej w dziele poety.

W niniejszym tekście wybrane nawiązania astronomiczne w Psalterzu Dawidowym zostaną zestawione $\mathrm{z}$ analogicznymi fragmentami dwóch najważniejszych przekładów wyznaniowych powstałych w XVI wieku: protestanckiej Biblii brzeskiej (1563) ${ }^{10}$ i katolickiej Biblii Wujka (1599, Psałterz Dawidów 1594). Ma to na celu nie szukanie bezpośrednich zależności, ale skonfrontowanie obrazu kosmosu w dziele poetyckim z tekstem tłumaczeń konfesyjnych, osadzonych w innych koncepcjach czytania i przekładania Pisma Świętego, o wiele bliższych oryginałowi hebrajskiemu (Biblia brzeska) lub Wulgacie (Wujek). Inspiracje poety i różne zależności stylistyczno-językowe przebadano już dość dobrze i nie one są tu przedmiotem zainteresowania (badanie takie byłoby zresztą niemożliwe, gdyż przekład Wujka wydano po śmierci Kochanowskiego).

10 Przekłady Kochanowskiego i brzeski porównała pod kątem stylistyczno-językowym E. Ostrowska, Walka o piękne słowo psałterzowe, ,Język Polski” 1953 nr 4, s. 285-317. 
Dla porządku należy przypomnieć jedynie kilka podstawowych ustaleń badaczy. Poeta korzystał z różnych przekładów, opartych zarówno na Wulgacie, jak i hebrajskim oryginale (choć hebrajskiego nie znał), ale żadnego nie naśladował niewolniczo. Wyjątkowo cenił pracę Buchanana, obaj humaniści wybrali bardziej poważaną formę poetycką, nie prozatorską, i obficie wykorzystali w swych parafrazach strofikę horacjańską. Zabieg ten wiąże się z odczytaniem psalmów - czyli hymnów - jako biblijnego odpowiednika rzymskich ód i natchnionej poezji Orfeusza. Poeta inspirował się również wersyfikacją biblijną ${ }^{11}$.

W słynnym liście do Fogelwedera Kochanowski opisuje swe rozdarcie między Koniecznością i Poetyką, wiernością oryginałowi i twórczym natchnieniem. Z jednej strony włącza się w nurt ponadwyznaniowego humanizmu chrześcijańskiego i podchodzi do tekstu racjonalnie i historycznie: unika zarówno poganizmów, jak i interpretacji chrześcijańskiej. W tekście brak więc zarówno Jowisza, jak i Chrystusa. Z drugiej - twórca poświęca ścisłość filologiczną dla piękna języka - poetyckiego, różnorodnego, melodyjnego ${ }^{12}$.

\section{Wschody i zachody słońca}

Wschody i zachody słońca, jeden z najczęściej przywoływanych motywów astronomicznych w Psałterzu, wiążą się zarówno z czasem, jak i przestrzenią: odmierzają noce i dni, ale też wyznaczają strony świata i określają jego granice. Do opisu pór dnia jednak poeta chętniej odnosi poranną i wieczorną zorzę, a słowa „wschód” i „zachód” wybiera raczej do określeń geograficznych. To raczej nie momenty czy pory doby, ale rejony, gdzie wschodzi lub zachodzi słońce, choć wzmianki o nich na

11 P. Buchwald-Pelcowa, Wstęp, dz. cyt., s. III-V; E. Buszewicz, Psałterz Dawidów, dz. cyt., s. 27-30, 36-40, 40-49, 53-54; J. Pelc, Kochanowski. Szczyt renesansu w literaturze polskiej, dz. cyt., s. 290-291, 482-488, 494-496, 501, 505-509, 518-519, J. Ziomek, Wstęp, [w:] J. Kochanowski, Psałterz Dawidów, opr. J. Ziomek, Wrocław 1960, s. XLIV-LXXVII, CXI.

12 E. Buszewicz, Psałterz Dawidów, dz. cyt., s. 30-31, 64; J. Pelc, Kochanowski. Szczyt renesansu w literaturze polskiej, dz. cyt., s. 289-291, 492-494; M. Kossowska, Biblia w języku polskim, t. 1, Poznań 1968, s. 304-311. 
zasadzie metonimii łączą się ze zjawiskiem astronomicznym czy nawet obrazem słońca chowającego się w morze wśród zorzy (Ps $66^{13}$ ). Przywołania wschodu i zachodu stanowią mniej lub bardziej rozbudowane amplifikacje zbudowane wokół określeń w rodzaju „wszystka ziemia”, „wszystki granice ziemie”, „kraje ziemie” czy „wszystkie kraje ziemie". Wzbogacają opis przestrzeni w psalmie, podczas gdy Biblia brzeska i Wujek zachowują wersję bliższą tekstowi hebrajskiemu i Wulgacie - jak w Ps 2, 33 ${ }^{14}$, 66 i $67^{15}$.

Dam ci w dziedzictwo wszytko ludzkie plemię,

Będziesz panował, będziesz rządził ziemię

I tam, gdzie wschodzi, i gdzie słońce padnie (K: Ps 2, 22-24).

[...] podam narody w dziedzictwo twoje, a w osiadłość twą granice ziemie (B: Ps 2, 8).

[...] dam ci pogany dziedzictwo twoje

a osiadłość twą kraje ziemie (W: Ps 2, 8).

Wszystka ziemia, wszystki kraje,

I gdzie jasne słońce wstaje,

I gdzie w bystre, szumne morze

Zapadają późne zorze,

Wykrzyknięte w słodkim pieniu (K: Ps 66, 1-5).

[...] Niechajże Bogu wykrzyka wszytka ziemia (B: Ps 66, 1).

Wykrzykajcie Bogu, wszytka ziemio! (W: Ps 65, 1).

13 S. Urbańczyk, Uwagi o artyzmie Psałterza w przekładzie Jana Kochanowskiego, „Język Polski” 1980 nr 5, s. 326-327.

14 K: Ps 33, 15-16; B: Ps 33, 8; W: Ps 32, 8.

Skrót „K” odnosi się do edycji: J. Kochanowski, Psałterz Dawidów, cz. 1: Fototypia - transkrypcja. List Jana Kochanowskiego do Stanisława Fogelwedera, oprac. J. Woronczak, Wrocław-Warszawa-Kraków-Gdańsk-Łódź 1982. Numery wersów oznaczają wersy parafrazy, a nie biblijnego oryginału. Uwspółcześniono pisownię samogłosek pochylonych. Skrót „B” odnosi się do edycji: Biblia brzeska 1563, red. Peter Krolikowski, Clifton-Kraków 2003.

Skrót „W” odnosi się do edycji Biblia w przekładzie księdza Jakuba Wujka z 1599 r., transkrypcja typu „B” oryginalnego tekstu z XVI w. i wstępy ks. J. Frankowski, Warszawa 2009.

15 K: Ps 67, 11-12; B: Ps 67, 8; W: Ps 66, 8. 
Dodatki Kochanowskiego wywodzą się z biblijnego opisu kręgu ziemi rozciągającego się od wschodu do zachodu. Obraz ten pojawia się zarówno u Kochanowskiego, jak i w przekładach prozą. Wskazuje na ziemię jako całość dzięki odwołaniu do jej krańców, którym patronują początek i koniec drogi słońca po niebie oraz wyznaczane przez nie przeciwstawne kierunki geograficzne. Przywołanie tej opozycji uwypukla ogromne rozmiary ziemi zdolnej pomieścić rzeczy tak odległe, że pozornie wykluczające się (Ps 50, 102, $107^{16}, 113^{17}$ ).

Pozowie ziemię od wschodnej granice

Aż do słonecznej późnej łożnice (K: Ps 50, 3-4).

[...] wezwał wszytkiej ziemie, od wschodu słońca aż do zachodu jej (B: Ps 50, 1).

[...] i przyzwał ziemie

od słońca wschodu aż do zachodu (W: Ps 49, 1).

Jako wschód od zachodu daleko pała,

Tak On od nas daleko grzech nasz oddala (K: Ps 103, 23-24).

Jako daleko jest wschód słońca od zachodu, tak daleko od nas oddalił przestępstwa nasze (B: Ps 103, 12).

Jako daleko jest wschód od zachodu,

daleko oddalił od nas nieprawości nasze (W: Ps 102, 12).

Cała wielka ziemia i tak liczne i różne ludy ją zamieszkujące mają wychwalać swego Stwórcę i uznawać Jego władzę nad sobą. Ogrom Jego dzieła świadczy o Jego potędze, a także o miłosierdziu: w Psalmie 103 przebaczający Bóg oddala grzechy od ludzi na całą szerokość świata: dystans między jego wschodnim i zachodnim krańcem. W Psalmie 106 opis całości ziemi dopełnia druga oś północ-południe. O ile Biblia brzeska i Wujek wymieniają tu po prostu cztery kierunki (przy czym Wujek zamienia południe na morze za Wulgatą), o tyle Kochanowski wzorem Psalmów 50, 103 i 113 łączy wschód i zachód ze zjawiskami astronomicznymi, północy dodaje jej pogodowy „atrybut”: akwilon,

16 K: Ps 107, 5-8; B: Ps 107, 3; W: Ps 106, 2-3.

17 K: Ps 113, 5-6; B: Ps 113, 3; W: Ps 112, 3. 
a południe wiąże z obrazem pól, skierowanych ku najbardziej nasłonecznionej stronie.

Dwukrotnie u Kochanowskiego jedna para kierunków uzupełnia drugą. W Psalmie 75 do oryginalnych wschodu i zachodu poeta dodaje południe i północ reprezentowaną przez akwilon (a także po raz kolejny wschodzące lub zachodzące słońce). Natomiast w Psalmie 89 rezygnuje z gór Tabor i Hermon, by w zamian północy i południu (w Wujka znów morze) towarzyszyły zachód i wschód słońca, wyraźnie reprezentowane przez zjawisko astronomiczne, określone epitetem „różany” - od blasku zorzy.

Próżno sie sławy albo ode wschodu,

Albo spodziewać od słońca zachodu;

Ani z południa przyjdzie, ani ona

Od akwilona (K: Ps 75, 17-20).

Abowiem ani od wschodu słońca, ani od zachodu, ani od puszczej przychodzi wywyższenie (B: Ps 75, 7).

Bo ani od wschodu, ani od zachodu, ani od pustych gór (W: Ps 74, 7).

Twe jest niebo. Twa ziemia, wszytko musi Tobie

Przypisać, cokolwiek świat wielki zamknął w sobie.

Południe i pół nocy, wschód słońca różany

I zachód Twym dowcipem stoi zbudowany (K: Ps 89, 21).

Twojeć są niebiosa i twojać jest ziemia, a tyś ugruntował okrąg świata i wszytko co na nim jest.

Tyś stworzył północ i południe, a w twym imieniu weselą się Tabor i Hermon

(B: Ps 89, 12-13).

Twojeć są niebiosa i twoja też jest ziemia,

tyś ugruntował okrąg ziemie i napełnienie jej:

tyś stworzył północną stronę i morze,

Tabor i Hermon w imieniu twym radować się będą (W: Ps 88, 12-13).

Obraz ziemi jako całości opisanej przez kierunki geograficzne i okrążanej przez słońce Kochanowski wprowadza też w Psalmie 19 w miejscu, 
gdzie w przekładach prozą pojawiają się po prostu krańce nieba (a zarazem ziemi „stykającej się” z nieboskłonem na horyzoncie). Motyw ten łączy się z obrazem słońca - oblubieńca wychodzącego o świcie ze swych komnat.

Od wschodnich granic wynika ku biegu,

A zostawa sie na zachodnym brzegu (K: Ps 19, 25-26).

Od końca niebios jest wyście jego, a wejście jego aż na drugim końcu ich, a nie jest nikt coby się miał zakryć od gorącości jego (B: Ps 19, 7).

Od kraju nieba wyjście jego,

a nawrót jego aż na kraj jego,

a nie masz, kto by się mógł zakryć od gorącości jego (W: Ps 18, 7).

Zainspirowany biblijnym zespoleniem codziennych zjawisk astronomicznych i kierunków geograficznych Kochanowski przywołuje je chętniej niż autor biblijny. Tym samym wprowadza do Psałterza dodatkowe elementy przyrodnicze, a nawet - choć rzadziej - przywołuje wdzięczny obraz zorzy. Z jednej strony to motyw konwencjonalny, ukazany przeważnie bez obrazowych szczegółów. Z drugiej - trudno nie docenić uwagi, jaką poświęcił mu poeta. Nie tylko urozmaica określenia krańców i stron świata, lecz także daje wyobrażenie o budowie kosmosu w psalmach. Ziemia wydaje się tu płaska, a jej granice wyznaczają morze na horyzoncie i niebo, po którym porusza się Słońce. Kochanowski przejmuje więc kosmologię żydowską, wyrosłą z mitologii Mezopotamii. Nie przywołuje tu greckiego modelu geocentrycznego, podobnie jak $\mathrm{w}$ imię historyzmu nie posługuje się mitologicznym sztafażem w rodzaju Zeusa - Boga (jak już wspomniano).

\section{Krąg niebieski}

Jedną z cech nieba, którą wymienia Kochanowski w amplifikacjach, jest kolistość nieba. Kształt ten nietrudno powiązać z obrotami słońca, księżyca i gwiazd dającymi pojęcie o doskonałości harmonijnego kosmosu. Wskazują na nią sama symbolika koła - figury doskonałej-oraz 
cykliczność czasu wyznaczanego przez obiekty astronomiczne. Rytm czasu świadczy nie tylko o porządku Bożego dzieła, lecz także o jego trwałości i stanowi namiastkę wieczności. Dlatego w Psalmie 145 poeta zastępuje biblijne „wieki wieków” odwołaniem do przyrody: stworzenie będzie wielbiło swego Stwórcę nie przez nieskończenie liczne odcinki czasu, ale dopóki przetrwa niewzruszony rytm przemian dnia i nocy. Poeta przywołuje zdecydowanie krótszą niż wiek dobę i ukonkretnia obraz. Niezmienność oddawania czci Bogu przez Jego dzieło wynika z niezmienności owego dzieła; zostało ono tak zaprojektowane, że chwała należna jego Autorowi niejako musi być Mu składana, stanowi naturalny mechanizm, tkwi w istocie kosmosu. Stałość wysławiania Najwyższego wynika więc niejako sama z siebie, jest jednocześnie przyczyną oraz skutkiem i tym samym zatacza dodatkowy „krąg”.

A wszelka żywa dusza imię święte Twoje

Wielbić będzie tak długo, póki nieodmiennym

Kołem pójdzie gwieździsta noc za światłem dziennym (K: Ps 145, 38-40).

[...] a wszelkie ciało dobrorzeczyć będzie świętemu imieniowi jego aż na wieki wieczne (B: Ps 145, 21).

[...] a wszelkie ciało niechaj błogosławi imię święte jego na wieki i na wieki wieków (W: Ps 144, 21).

Stwórca niebiańskich kręgów jednocześnie nimi rządzi, podtrzymuje istnienie swego dzieła. Niebo pełni u Kochanowskiego nie tyle funkcję atrybutu i siedziby, ile wskazuje na nadrzędną pozycję Najwyższego, który uczynił świat doskonałym, czuwa nad nim i z góry widzi wszystko, co się w nim dzieje. Nieprzypadkowo w Psalmie 135 poeta używa słowa „sprawuje”, czyli „kieruje, powoduje”18. Pobrzmiewa tu echo schrystianizowanej arystotelesowsko-ptolemejskiej wizji kosmosu, w którym sfery niebieskie obracają się z miłości do Boga, górującego nad nimi z empireum umieszczonego tuż nad ostatnią z kul - Primum

18 Stownik staropolski, http://www.staropolska.pl/slownik/?nr=0\&litera=sprawowa $\%$ C4\% 87\&id=2174 (10.11.2019). 
Mobile ${ }^{19}$. Stwórca fizycznie znajduje się tu ponad człowiekiem. Motyw Boga ponad obracającymi się niebiosami nie wyklucza się również z kosmologią biblijną.

Chwalcie Pana, który krąg niebieski sprawuje (K: Ps 136, 49).

Wysławiajcież Boga niebieskiego [...] (B: Ps 136, 26).

Wyznawajcie Boga nieba [...] (W: Ps 135, 26).

[...] bo Ty nad wszytkiemi

Koły siedząc niebieskiemi

Na niskość przedsię patrzysz i to, co wysoko,

Z daleka zna Twoje oko. (K: Ps 138, 15-18).

Abowiem nawyższy Pan pogląda na rzeczy niskie, a wysokie z daleka poznawa

(B: Ps 138, 6).

Abowiem wysoki Pan, a na niskie patrzy,

a wysokie z daleka poznawa (W: Ps 137 6).

Górowanie (dosłowne i w przenośni) Boga nad stworzeniem poeta często opisuje, podkreślając Jego pozycję „na wysokościach” przeciwstawioną „niskiej ziemi” w domyśle lub bezpośrednio. Zarówno u Kochanowskiego, jak i w przekładach prozą „wysokość” stanowi synonim nieba, pojawia się wraz z nim (Ps $14^{20}, 121^{21}, 135^{22}$ ), może je nawet zastąpić (Ps $2^{23}$ ) - tak samo przecież określa miejsce, w którym mieszka Stwórca.

Mieszkanie na wysokościach oznacza nie tylko uprzywilejowanie i władzę, lecz także wszechwiedzę zobrazowaną w motywie patrzenia na człowieka z góry, skąd widać wszystko. Najwyższy ogarnia niebo i ziemię, zna prawdę o każdym stworzeniu, żadne z nich nie ukryje się przed nim. Dystans przestrzenny podkreśla miejsce Stwórcy na

19 C. S. Lewis, Odrzucony obraz. Wprowadzenie do literatury średniowiecza i renesansu, przeł. W. Ostrowski, Kraków 1995, s. 95-97, 102, 114-116.

20 K: Ps 14, 5-6; B: Ps 14, 3; W: Ps 13, 2.

21 K: Ps 121, 5-8; B: Ps 121, 2; W: Ps 120, 2.

22 K: Ps 135, 9-10; B: Ps 135, 6; W: Ps 134, 6.

23 K: Ps 2, 9-10; B: Ps 2, 4; W: Ps 2, 4. 
szczycie hierarchii bytów, Jego transcendencję oraz niezależność, wagę, wiarygodność i obiektywność Jego sądów. Jego zamysły i potęga przerastają człowieka, są dla niego nieuchwytne, co poeta wyraża słowem bujać, w ówczesnej polszczyźnie związanym nie tylko ze swobodą, lecz także z pychą i przekraczaniem miary ${ }^{24}$. To może jednak dotyczyć tylko człowieka niesłusznie stawiającego siebie na pierwszym miejscu - Bogu ono się należy, tak samo jak z zasady nie mieści się On w ludzkich kategoriach i tym samym „przekracza” ludzką miarę.

Ten ma narody wszytki pod nogami,

A Jego sława buja nad gwiazdami.

Kto kiedy z Panem tym porowna, który

Dziwnie wysoko siedząc przecie z góry

I co na niebie, i co jest na ziemi

Oczyma widzi nieuchronionemi? (K: Ps 113, 7-12).

Wywyższon jest Pan nad wszytkiemi narody, a chwała jego nad niebiosa.

I któż jest takim jako Pan, Bóg nasz? Który mieszka na wysokości?

Który się zniża, aby widział to, co jest na niebie i na ziemi (B: Ps 113, 4-6).

Wysoki nad wszystkie narody Pan

a nad niebiosa chwała jego.

Któż jako Pan Bóg nasz,

który mieszka na wysokości,

a na niskie rzeczy patrzy na niebie i na ziemi? (W: Ps 112, 4-6).

W Psalmie 113 pojawia się rozróżnienie nieba fizycznego i metafizycznego, które Kochanowski podkreśla, zastępując niebo gwiazdami. To ponad nimi znajduje się Bóg otaczany chwałą przez zastępy aniołów. Panuje On zarówno nad mieszkańcami ziemi, jak i nieba - czyli nad ludźmi, nad ciałami niebieskimi, nad duchami niebios. Jest dobrym władcą - angażuje się w sprawy ziemskie, czuwa nad stworzeniem, podejmuje sprawiedliwe decyzje co do niego, dostrzega krzywdę biednych i nie pozostawia ich samych sobie. Jako potężny Sędzia, niezależny od ziemskich spraw, jest jedynym ratunkiem dla prześladowanych, którym

24 Słownik polszczyzny XVI wieku, t. 2, red. S. Bąk et al., Wrocław-Warszawa 1967. 
nikt na ziemi już nie może pomóc. Jego sprawiedliwe wyroki wiążą się z odpowiedzialnością za stworzenie jego Twórcy i Władcy, jedynego, kto zna je w pełni (Ps $\left.16^{25}, 90,121\right)$.

Królu na wysokim niebie,

Nie ma indziej, okrom Ciebie,

Człowiek nieszcześciem strapiony

Ucieczki ani obrony.

Pierwej, niżli góry wstały,

Niż ziemia, niż okazały

Krąg niebieski jest stworzony,

Tyś jest, Boże nieskończony! (K: Ps 90,1-8).

[...] Tyś Panie był naszą ucieczką od wiekuistych czasów.

Pierwej niżli się góry zstały i niżliś wykształtował ziemię i okrąg świata, tedyś ty jest

Bogiem [...] (B: Ps 90, 1-2).

[...] Panie, stałeś się ucieczką nam,

od rodzaju do rodzaju.

Pierwej niżli stanęły góry abo ziemia i świat był stworzony

[...] ty jesteś Bóg. (W: Ps 89, 1-2).

Duszo moja, przedsię ty tusz dobrze sobie:

Bóg w nieszcześciu twym będzie pomocen tobie.

Bóg ten, który wysokie niebo zbudował

I ziemski wszytkorodny krąg ugruntował (K: Ps 121, 5-8).

Aleć mój ratunek od Pana, który stworzył niebo i ziemię (B: Ps 121, 2).

Pomoc moja od Pana,

który stworzył niebo i ziemię (W: Ps 120, 2).

Kochanowski do wołań o pomoc wprowadza przeciwstawienie człowieka w dole i Boga na wysokościach. Rozbudowuje wezwania psalmisty, zaznacza, że doświadcza on nieszczęścia, nie ma innej nadziei niż ta pokładana w Najwyższym, którego mówiący w utworze wzywa nie tylko z „niskiej” ziemi, po prostu niższej od niebios, lecz także z „głębokości” 
smutku i trudności. W błaganiu tym łączy się niejako cały kosmos: stworzenie wzywa Stwórcę.

Niebo można tu rozumieć dwojako: fizycznie i metafizycznie. W Psalmie 90 ziemię i świat poeta zamienia na ziemię i krąg niebieski, znów - jak się zdaje - odróżniony od nieba, siedziby Boga. Niebo astronomiczne przynależy więc w pewien sposób do świata ziemskiego, nad którym góruje Pan na wysokościach nieba metafizycznego. Taki podział potwierdza Psalm 121, gdzie poeta wspomina o kręgu ziemi i budowaniu nieba, odwołując się do motywu Boga architekta wyznaczającego ruch ciał niebieskich. Przyroda stanowi w psalmach całość rządzoną rozumnymi zasadami, określonymi przez Stwórcę. O ich doskonałości (oraz oczywiście o kształcie) daje pojęcie ich kolistość, przy czym boska figura kręgu określa zarówno ziemię, jak i niebiosa. Choć atrybut wysokości poeta wiąże przeważnie z siedzibą Boga, wysoki może być również nieboskłon (Ps $135^{26}$ ).

Siedzibę Boga Kochanowski stylizuje na rezydencję ziemskiego władcy. Czyni to śladem autora biblijnego i wspomina o stolicy na wysokości (czyli Syjonie, stolicy Dawida, Ps 7), z której Bóg będzie sprawiedliwie sądził ludy. W Psalmach 43 i 103 konkretyzuje obraz mieszkania Najwyższego: miasto staje się pałacami lub dworem, podczas gdy Biblia brzeska i Wujek pozostają przy biblijnych określeniach góra święta i stolica.

[...] oto lud w wielkiej gromadzie

Wyroku Twego czeka: jeśli złemu,

Czy upaść przed Twym sądem cnotliwemu?

Przeto, o sędzia, sędzia wiekuisty,

Chciej na wysokiej sieść stolicy swojej (K: Ps 7, 19-20).

Tedy zgromadzenie narodów zbieży się do ciebie, a dla niego usiądź na wysokości

(B: Ps 7, 8).

[...] a zgromadzenie narodów obstąpi cię

i dlatego wróć się na wysokość (W: Ps 7, 8).

26 K: Ps 135, 9-10; B: Ps 135, 6; W: Ps 134, 6. 
Niech Twej pomocy, Panie,

Światło prawdziwe wstanie,

Za którym i ja pójdę,

I Twych wysokich dojdę

Pałaców, gdzie mieszkanie,

Gdzie Ty masz przebywanie (K: Ps 43, 13-18).

Wypuść światłość twą i prawdę twoję, a ony mię poprowadzą i wywiodą na świętą górę twoję i do przybytków twoich (B: Ps 43, 3).

Wyśli światłość twoję i prawdę twoję:

te mię prowadziły i przyprowadziły

na Górę Świętą twoję i do przybytków twoich (W: Ps 42, 3).

Pan na ognistym niebie dwór swój wysoki

Zasadził, skąd panuje na świat szyroki (K: Ps 103, 37-38).

Pan postawił na niebie stolicę swoję, a królestwu jego są poddani wszyscy (B: Ps 103, 19).

Pan na niebie przygotował stolicę swoję,

a królestwo jego nad wszemi panować będzie (W: Ps 102, 19).

\section{Zorze}

Jednym z wyznaczników czasu w Psałterzu Kochanowskiego są zorze poranne i wieczorne porządkujące rytm kosmosu. Stają się znakiem ładu wszechświata, ponieważ towarzyszą przemianom dnia w noc i nocy w dzień. To w nich daje się namacalnie doświadczyć cykliczność przemian przyrody i czasu, a wraz z nimi - doskonałość zawartego w nich Bożego zamysłu. Prócz nich reprezentują też poranek (zorza poranna) i wieczór (zorza wieczorna), przy czym zdecydowanie liczniej reprezentowany jest początek dnia.

W Psalmie 104 pojawienie się zorzy zastępuje oryginalny wschód słońca, zachowany w przekładach prozą. Poeta zaznacza jego piękno: zjawisko kwitnie niczym barwny kwiat. Następuje ono po wieczorze i nocy, porze panowania mroku i dzikich zwierząt - znaków chaosu i niebezpieczeństwa. Wraz z nastaniem dnia cofają się one do 
nielicznych ostoi: ciemnych jaskiń. O ile przekłady prozą wspominają, że groźne stworzenia po prostu leżą w nich, o tyle Kochanowski stwierdza, że „źwierz do jaskiń uchodzi” - jak pokonany przed silniejszym przeciwnikiem. Tym samym ustępują pola człowiekowi, który zaprowadza w świecie porządek i gospodaruje przyrodą aż do wieczora, gdy skończy się panowanie światła i rozumu oraz nadejdzie czas spoczynku po pracy.

Skoro zaś jasna zorza zakwitnie na niebie,

Źwierz do jaskiń uchodzi, ludzie następują

Na roboty, gdzie także do mroku pracują (K: Ps 104, 42-44).

Lecz skoro słońce wznidzie, wnet się zgromadzają, a leżą w jamach swoich.

Tedy człowiek wychodzi ku robocie swojej i ku sprawam swoim aż do wieczora (B: Ps 104, 22-23).

Wzeszło słońce i zgromadzili się, i w jamach swoich położą się.

Wynidzie człowiek na robotę swoję

i na sprawy swoje aż do wieczora (W: Ps 103, 22-23).

Zorza poranna oznacza nie tylko nastanie pory panowania ładu i rozumu, lecz także światło nadziei. W Psalmie 5 człowiek smutny już od świtu kieruje do Boga swe prośby o ratunek, patrząc w niebo, gdzie właśnie pojawiło się słońce i gdzie sytuuje się metafizyczne „w górze”. Określenie nastroju bohatera pochodzi od Kochanowskiego, a z całości utworu można się raczej go domyślać. Modlitwa o tak wczesnej porze oznacza gorliwą pobożność mówiącego, której brak występnym. Wskazuje też na głębię jego utrapienia - niepokoi ono i zmusza do czuwania lub przynajmniej ułatwia je.

Ledwe z głębokiego morza

Ukaże się rana zorza,

A ja już wołam do Ciebie

Smutne oczy mając w niebie (K: Ps 5, 5-8).

Panie, wysłuchasz głos mój z poranku, abowiem rano zgotuję k tobie modlitwę moję i będę się przypatrywał (B: Ps 5, 4). 
[...] rano wysłuchasz głos mój.

Rano będę stał przed tobą i ujźrzę [...] (W: Ps 5, 4-5).

W Psalmie 14 (zob. też zakończenie Psalmu 53) poranna modlitwa dotyczy już nie udręczonej jednostki, ale całego Izraela. Co ciekawe, Kochanowski zastępuje zorzą Syjon, zachowany w przekładach brzeskim i Wujka. Oba motywy wiążą się z mitycznym „w górze”, siedzibą sacrum. Poeta wybiera jednak nie stolicę, miasto święte, świętą górę, symbol narodu, ale bardziej uniwersalny, ponadreligijny obraz wzięty z natury, coranną przypowieść o Bożym zamyśle i porządku zapisanym w stworzeniu. To ład natury i rodzące się po raz kolejny światło mają przynieść zbiorowości nadzieję, nie kult religijny pośredniczący między człowiekiem i Bogiem, czczonym w Jerozolimie - Syjonie.

Gdzieś to ta pożądna zorza

Wyniknęła rychło z morza,

Gdy też nas z ciężkiej niewoli

Pan nasz i Bóg nasz wyzwoli! (K: Ps 14, 25).

Któż da z Syjonu wybawienie Izraelowi? Gdy Pan wybawi z więzienia lud swój, rozraduje się Jakub, a rozweseli się Izrael (B: Ps 14, 8).

Któż da z Syjonu zbawienie Izraelskie?

Gdy oddali Pan niewolą ludu swego,

rozweseli się Jakub i rozraduje się Izrael (W: Ps 13, 7).

Podobna modyfikacja dokonała się w Psalmie 133. Miłość i zgodę poeta porównuje za psalmistą do rosy - nie zstępuje ona jednak na Syjon z wysokości szczytu Hermonu na niższy Sirion, który nietrudno utożsamić z Syjonem i wzbogacić o znaczenie symboliczne, jak zapewne stało się w Biblii brzeskiej i Biblii Wujka. Tam, gdzie przekłady prozą zawierają zdanie przydawkowe o zstępującej rosie, Kochanowski umieszcza zdanie okolicznikowe czasu - perłowe krople zdobią świat o świcie - oraz dodaje liczne obrazowe szczegóły: perłowe połysk i barwę rosy, pokryte przez nią pastwiska, ognistą barwę zorzy, morze. Dość niejasny oryginalny obraz zastępuje motywem uniwersalnym, wzbogaconym efektownym detalem. 
Nie tak rozkoszne krople są perłowe

Niebieskiej rossy, które Hormonowe

Pastwiska zdobią, kiedy wstaje z morza

Ognista zorza (K: Ps 133, 9-12).

Jest też jako rosa Hermon, która zstępuje na góry Syjon [...] (B: Ps 133, 3).

jako rosa Hermon, która zstępuje na górę Syjon [...] (W: Ps 132, 3).

Zorza oznacza w Psałterzu również blask cnoty, zwłaszcza tej docenionej, szanowanej, stanowiącej przykład dla innych. W Psalmie 37 poeta czyni zorzę konkretniejszą postacią światła wymienianego przez oryginał i przekłady prozą, zamiast południa zaś pisze o słońcu. Również w Psalmie 110 porównuje cnotę i żywotność ludu do różanej zorzy - świetlistej, zwiastującej odrodzenie, o barwie symbolizującej życie. Zrywa tym samym z tradycją Wulgaty, zawierającej słowa o narodzinach króla przed jutrzenką, co czytano jako zapowiedź mesjańską. Zdecydowanie bliżej Kochanowskiemu do przekładu brzeskiego.

Jasna jest zorza, jasno słóńce pała,

Tak będzie i twa cnota okazała (K: Ps 37, 13-14).

I wywiedzie sprawiedliwość twą jako światłość, a prawo twe jako południe (B: Ps 37, 6).

I wywiedzie jako światłość sprawiedliwość twoję,

a sąd twój jako południe (W: Ps 36, 6).

Lud w cnotach okazały, świetny w pobożności,

Rosa różanej żarze, krew twojej młodości (K: Ps 110, 11-12).

[...] a rozrodzenie twoje będzie z żywota jako rosa na świtaniu (B: Ps 110, 3).

[...] Z żywota przed jutrzenką zrodziłem cię (W: Ps 109, 3).

\section{Słońce i księżyc}

Ponieważ kosmiczny ład porządkuje ruch najjaśniejszych ciał niebieskich: Słońca i Księżyca, nie dziwi, że występują one w psalmach w parze. Jako władcy nocy i dnia wyznaczają podział doby. Co ciekawe, 
Kochanowski raczej nie wprowadza tego motywu niezależnie od psalmisty: w przeciwieństwie do wschodów i zachodów słońca czy zorzy para słońce i księżyc pojawia się tylko tam, gdzie wspomina ją psalmista, oczywiście zazwyczaj wzbogacona o epitety i poetyckie obrazy. Najczęściej towarzyszy pochwałom Bożego zamysłu w przyrodzie, jej piękna i harmonii, jak w Psalmie 104.

Tyś na znak czasów sprawił błędną twarz miesięczną,

Ty niepoścignionego słońca lampę wdzięczną

Prowadzisz do zachodu [...] (K: Ps 104, 39).

Sprawił miesiąc na czasy, a słońce wie zachód swój (B: Ps 104, 19).

Uczynił księżyc dla czasów,

słońce poznało zachód swój (W: Ps 103, 19).

Ciała niebieskie reprezentują swego Stwórcę, są Jego „zarządcami”. Za ich pomocą Najwyższy strzeże niezmiennych zasad, które wyznaczył, i podtrzymuje istnienie kosmosu. U Kochanowskiego nie odmierzają jedynie czasu jak w przekładach prozą, ale również wiecznie wędrują - księżyc błądzi, czyli krąży, tuła się, słońce jest niepoścignione, nie sposób do dogonić ani zatrzymać jego ruchu. Poeta odwołuje się do wyglądu ciał niebieskich: „twarzy” księżyca, ułożonej z mórz księżycowych, dobrze znanej z ikonografii, oraz świetlistości słońca - lampy oświetlającej cały sferyczny kosmos. W przeciwieństwie do przekładów bliższych oryginału Kochanowski uwydatnia rolę Boga: słońce nie poznało reguł swego ruchu, ale sam Najwyższy je prowadzi ku zachodowi, gdy zakończy swój dzienny bieg.

O ładzie natury mogą też mówić pory dnia: dzień i noc oraz poranek i wieczór. Podobnie jak słońce i księżyc podlegają dobroczynnej władzy miłosiernego Boga, który w swej dobroci określił zasady funkcjonowania kosmosu i czuwa, by ich nie naruszono. Jego działanie raduje całe stworzenie - u Kochanowskiego za Wulgatą ${ }^{27}$ cieszy się przyroda: świt i zmierzch, podczas gdy Wujek wybiera interpretację przestrzenną

27 exitus matutini et vespere delectabis - za: Vulgata Clementina, http://vulsearch.sourceforge. net/html/Ps.html (10.11.2019). 
i pisze o krajach poranka i wieczoru, czyli wschodu i zachodu. Weselą się więc mieszkańcy całej ziemi, zapewne jak w Biblii brzeskiej, w której jednak dość trudno precyzyjnie określić, kto się raduje (w intencji tłumacza przypuszczalnie granice ziemi, ale można też uznać, że cuda). Wiadomo natomiast, że dzieje się to o wschodzie i zachodzie słońca i - jak informuje przypis - właśnie z powodu owych zjawisk. Przekład Kochanowskiego jest bliższy tej drugiej interpretacji, silniej związanej z czasem niż przestrzenią.

Twych gromów srogich ludzie sie lękają,

Którzy w nadalszych krainach mieszkają;

Ty uweselasz rany świt pozorny

I mirzk wieczorny (K: Ps 65, 29-32).

I lękają się mieszkający na granicach ziemie cudów twoich, które rozweselasz, gdy nastawa zaranie i wieczór (B: Ps 65, 9).

i będą się bać, którzy mieszkają na krajach, dla znaków twoich:

kraje rana i wieczora ucieszysz (W: Ps 64, 9).

Zachwyt kosmicznym ładem sprawia, że psalmista pragnie wychwalać miłosierdzie Tego, który powołał świat do istnienia, ustalił jego prawa i nieustannie podtrzymuje jego trwanie. Ciała niebieskie stanowią ważny element biblijnych pochwał stworzenia (np. Ps $136^{28}, 148^{29}$ ). Kochanowski zmienia w nich niewiele, ale o tym, że je cenił, niezmiennie przypomina pieśń Czego chcesz od nas, Panie... Jak w niej, w parafrazach psalmów Słońce i księżyc z Bożego ustanowienia rządzą dniem i nocą. Ich blasku nie można zgasić, co świadczy o trwałości niebiańskiego porządku. Podziwia go człowiek, który wraz z przyrodą wysławia swego Pana pełny wdzięczności: psalmista - hymnami, ciała niebieskie - swym rytmicznym biegiem. W ten sposób każdy posłusznie wypełnia wolę Najwyższego stosownie do swego przeznaczenia, a tym samym wpisuje się w całość Bożego dzieła i współtworzy jego harmonię.

28 K: Ps 136, 13-18; B: Ps 136, 7-9; W: Ps 135, 7-9.

29 K: Ps 148, 7-8; B: Ps 148, 3; W: Ps 148, 3. 
Niezmienność biegu słońca i księżyca ściśle wiążą się z zachowaniem bytu kosmosu. Dopóki krążą one po niebie, istnieje świat. Dlatego, gdy psalmista pragnie podkreślić trwałość królewskiego rodu Dawida, stwierdza, że koniec sławy dynastii i życie jej kolejnych członków nastanie wraz z końcem wędrówki ciał niebieskich, czyli końcem wszystkiego. Cykliczna ciągłość rytmu natury nakłada się tu na linearną ciągłość następujących po sobie pokoleń, choć przyroda jest zdecydowanie stabilniejsza od rodu panującego - jego dobrobyt zależy od łaski Boga i posłuszeństwa Najwyższemu. Jeśli niezależnie od tego Stwórca obiecuje umocnienie potomstwa Dawida na wieki, stanowi to nadzwyczajny dowód miłosierdzia i przekracza porządek ludzki właśnie w stronę porządku przyrody.

Kochanowski po raz kolejny, jak w Psalmach 104 i 135, podkreśla amplifikacją niezmienność biegu ciał niebieskich: nazywa je „strażą czujną świata” (Ps 72), księżyc jest „nieuchodzony”, słońce leci „szlakiem dawnym” (Ps 89). Ich ruch jest odwieczny, nie ma końca i odbywa się z nakazu Stwórcy, którego zamysłu strzegą obiekty astronomiczne.

I będzie jego imię na ziemi

Miedzy narody straszne wszytkiemi

Tak długo, póki straż czujna świata,

Miesiąc i słońce poniosą lata (K: Ps 72, 9-12).

A póki jedno słońce i miesiąc będzie trwać, będą się bać ciebie po wszytki wieki (B: Ps 72, 5).

I będzie trwał z słońcem i przed księżycem, na pokolenie i pokolenie (W: Ps 71, 5).

Nie ma ustać potomstwo w domu jego sławnym

Ani zacny tron jego, póki szlakiem dawnym

Prędkie słońce poleci i nieuchodzony

Krąg miesięczny, a iściec na niebie niepłony (K: Ps 89, 65-68).

Potomstwo jego zostanie na wieki, a stolica jego będzie jako słońce przede mną.

I będzie umocniony jako miesiąc na wieki, będąc jako wiernym świadkiem na niebie [...]

(B: Ps 89, 37-38).

Nasienie jego będzie trwać na wieki, 
a stolica jego, jako słońce przed oczyma memi

i jako pełny księżyc na wieki

i świadek wierny na niebie (W: Ps 88, 37-38).

Odwołania do ciał niebieskich budują również stwierdzenia, że coś będzie się działo zawsze nie tylko w planie całych dziejów, lecz także w skali ludzkiego życia, regulowanego przez rytm doby. W Psalmie $121^{30}$ Bóg strzeże człowieka stale, o każdej porze: chroni go przed słońcem i księżycem, przed upałem dnia i chłodem nocy, reprezentowanymi przez obiekty astronomiczne. Człowiek w odpowiedzi wzywa go dniem i nocą, wymienianymi zwykle już bez słońca i księżyca, jak w Psalmach $55^{31}$ i $86^{32}$. Wyjątkowo chętnie czyni to oczywiście w utrapieniu, gdy najbardziej potrzebuje opieki Stwórcy.

\section{Podsumowanie}

W niniejszym tekście omówiono jedynie kilka motywów astronomicznych obecnych w Psałterzu Dawidowym Kochanowskiego, związanych z czasem i przestrzenią. Fragmenty poetyckiej parafrazy odniesiono do najważniejszych prozatorskich polskich przekładów Biblii z XVI wieku, dających pojęcie o lekturze bliższej oryginału, wyrastającej z przekonań poszczególnych wyznań. Jak wielokrotnie dowodzili badacze, mistrz z Czarnolasu starał się wznieść ponad podziały, unikał wypowiedzi nacechowanych konfesyjnie i skłaniał się ku uniwersalistycznemu chrześcijańskiemu humanizmowi ${ }^{33}$. Nieprzypadkowo jego psalmy wykorzystywali zarówno katolicy, jak i protestanci ${ }^{34}$. W przeciwieństwie do chrystocentrycznego Erazma bardziej niż wcielonym

30 K: Ps 121, 15-16; B: Ps 121, 6; W: Ps 120, 6.

31 K: Ps 55, 33; B: Ps 55, 18; W: Ps 54, 18.

32 K: Ps 86, 9-10; B: Ps 86, 3; W: Ps 85, 3.

33 E. Buszewicz, Psałterz Dawidów, dz. cyt., s. 50-51; J. Pelc, Kochanowski. Szczyt renesansu w literaturze polskiej, dz. cyt., 489-492, 496-499; W. Weintraub, Rzecz czarnoleska, dz. cyt., s. 239-254.

34 J. Pelc, Kochanowski. Szczyt renesansu w literaturze polskiej, dz. cyt., s. 22, 135, 485-486, 498-499. 
Słowem - Zbawicielem interesował się Bogiem starotestamentowym, Artystą-Stwórcą i Władcą harmonijnego kosmosu, Wieczną Myślą, Opatrznością ${ }^{35}$.

Piękno Bożego dzieła i rozumność jego praw poeta po wielokroć opiewa właśnie w psalmach, których tekst dość często wzbogaca o szczegóły budujące obrazki ze świata natury. Choć zgodnie z konstatacjami badaczy wspomnianymi we wstępie wpisują się one w konwencje literackie, świadczą o zainteresowaniu Kochanowskiego przyrodą, co prawda nie obserwowaną, ale opiewaną jako harmonijne dzieło Bożego rozumu. Jego porządek wyznaczają w dużej mierze ciała niebieskie, przywoływane tak chętnie - chętniej niż w przekładach prozatorskich. Twórca zachowuje starotestamentowe wyobrażenia o budowie wszechświata, ale mimowolnie uwzględnia też elementy obowiązującej schrystianizowanej kosmologii Ptolemeusza. W Psałterzu przenikają się więc mitologia biblijna, wpisująca się w ogólnoludzkie myślenie mityczne, oraz astronomia grecko-rzymska.

Nawiązania astronomiczne służą w pierwszej kolejności nie poznaniu nieba, ale wysławianiu jego Stwórcy. Namysł nad niebem astronomicznym ma kierować człowieka ku niebu metafizycznemu. Kochanowski poświęca wiele uwagi ciałom niebieskim, aby opisać ludzki zachwyt pięknym, harmonijnym kosmosem. Rozbudowuje biblijne wzmianki o nich, czym dowodzi swego poetyckiego kunsztu, któremu daje wyraz również w pochwałach stworzenia zawartych w Pieśniach, wyrosłych z tradycji psalmów.

\section{Abstrakt}

\section{Biblijna kosmologia Jana Kochanowskiego. Ciała niebieskie w „Psałterzu Dawidowym" na tle XVI-wiecznych przekładów Biblii}

Tematem tekstu są odniesienia astronomiczne w Psałterzu Dawidowym Jana Kochanowskiego, zaliczającym się do dzieł poety najbogatszych w tego typu

35 Tamże, s. 489-494, 522-523; E. Buszewicz, Psałterz Dawidów, dz. cyt., s. 61-62; W. Weintraub, Rzecz czarnoleska, dz. cyt., s. 239, 241; J. Ziomek, Wstęp, dz. cyt., LXIII-LXVI, LXXXII-CI. 
nawiązania. Koncentrują się one wokół budowy wszechświata, najważniejszych ciał niebieskich: Słońca i Księżyca (w dalszej kolejności też gwiazd) oraz ich ruchu po niebie, wyznaczanego przez nie kosmicznego ładu i pochwały harmonijnego dzieła Stworzenia oraz jego Autora. W tekście omówiono kilka wybranych motywów związanych z tematyką astronomiczną w Psałterzu. Zaliczają się do nich wschody i zachody słońca powiązane z porami dnia i porządkiem czasu, obraz kręgu ziemskiego, przeciwstawienie Bóg na wysokościach-ziemia na dole, zestawienia głównych obiektów astronomicznych: Słońca i Księżyca. Wybrane motywy astronomiczne w Psałterzu Kochanowskiego odniesiono do dwóch szesnastowiecznych tłumaczeń Księgi Psalmów, które można uznać za najważniejsze dla dwóch głównych stronnictw uczestniczących w sporach o teksty święte: protestancką Biblię brzeską i katolicką Biblię Jakuba Wujka. Nie ma to na celu szukania bezpośrednich zależności (w przypadku przekładu katolickiego, późniejszego niż zbiór Kochanowskiego, niemożliwych), ale skonfrontowanie dzieła poetyckiego z koncepcjami czytania i przekładania Biblii wykreowanymi przez twórców przekładów konfesyjnych.

Słowa kluczowe: kosmologia, Jan Kochanowski, Biblia, psałterz

\section{Abstract}

\section{Jan Kochanowski's biblical cosmology. Astronomical objects in "Psałterz Dawidów" in the 16th-century Bible translations backgound}

In the text, the astronomical references in Jan Kochanowski' Psatterz Dawidowy are discussed. This text is one of the richest of these motifs poet's works. The celestial themes focus on the structure of the universe, the most important celestial bodies: the Sun and the Moon (followed by stars) and their movement in the sky, the cosmic order and praise of the harmonious creation of the Creation and its Author. The text discusses selected motifs related to astronomical themes in the Psalter: sunrise and sunset, linked to the order of time, the image of the earth's circle, the opposition God in the heights - earth below, a pair of the most important astronomical objects: the Sun and the Moon. Selected astronomical motifs in Kochanowski's Psalter are compared to two sixteenth-century translations of the Book of Psalms, which can be considered the most important for the two main circles involved in disputes over holy texts: the Protestant Brest Bible and the Jakub Wujek's Catholic Bible. The article is not to seek direct dependencies (in the case of Catholic translation, later than the Kochanowski collection, they are impossible), but to confront the poetic work with the concepts of reading and translating the Bible created in the confessional translations.

Keywords: cosmology, Jan Kochanowski, Bible, psalter 


\section{References}

Axer, J. (1984). „Aratus” - miejsce poematu w twórczości Kochanowskiego. In T. Michałowska (Ed.), Jan Kochanowski i epoka renesansu. W 450 rocznice urodzin poety 1530-1980. Państwowe Wydawnictwo Naukowe.

Bąk, S., Hrabec, S., Kuraszkiewicz, W., Mayenowa, M. R., Rospond, S., Saski, S., Taszycki, W., \& Woronczak, J. (Eds.). (1967). Stownik polszczyzny XVI wieku (Vol. 2). Zakład Narodowy imienia Ossolińskich - Wydawnictwo Polskiej Akademii Nauk.

Buchwald-Pelcowa, P. (1985). Wstęp. In Psałterz Dawidów przekładania Jana Kochanowskiego. Instytut Wydawniczy Pax.

Buszewicz, E. (2001). Psałterz Dawidów. In A. Gorzkowski(Ed.), Jan Kochanowski. Universitas. Chlebowski, B. (1918). Poezja polska w wieku XVI. In S. Tarnowski (Ed.), Dzieje literatury pięknej w Polsce. Cz. 1. Akademia Umiejętności.

Frankowski, J. (Ed.). (2009). Biblia w przekładzie księdza Jakuba Wujka z 1599 r. Oficyna Wydawnicza Vocatio.

Kochanowski, J. (1982). Psałterz Dawidów. Cz. 1: Fototypia - transkrypcja. List Jana Kochanowskiego do Stanisława Fogelwedera (J. Woronczak, Ed.). Zakład Narodowy imienia Ossolińskich - Wydawnictwo Polskiej Akademii Nauk.

Kossowska, M. (1968). Biblia w języku polskim (Vol. 1). Księgarnia św. Wojciecha.

Królikowski, P., \& Radziwiłł, M. (Eds.). (2003). Biblia brzeska 1563. Kalwin Publishing, Collegium Columbinum.

Lewis, C. S. (1995). Odrzucony obraz. Wprowadzenie do literatury średniowiecznej i renesansowej (W. Ostrowski, Trans.). Społeczny Instytut Wydawniczy Znak.

Meller, K. (1997). Wstęp. In K. Meller (Ed.), Psałterz Dawidów. Towarzystwo Autorów i Wydawców Prac Naukowych Universitas.

Ostrowska, E. (1953). Walka o piękne słowo psałterzowe („Psałterz” Kochanowskiego i „Psałterz brzeski”). Język Polski, 4.

Ostrowska, E. (1973). O języku opisów przyrody w pieśniach. Język Polski, 1.

Pelc, J. (2001). Kochanowski. Szczyt renesansu w literaturze polskiej (3rd ed.). Wydawnictwo Naukowe PWN.

Przyroda w literaturze polskiej w epoce odrodzenia (dokończenie). (1906). Pamiętnik Literacki, 5(1-4).

Sokolski, J. (Ed.). (2010). Człowiek wobec natury - humanizm wobec nauk przyrodniczych. Wydawnictwo Neriton.

Urbańczyk, S. (1980). Uwagi o artyzmie Psałterza w przekładzie Jana Kochanowskiego. Język Polski, 5.

Weintraub, W. (1977). Rzecz czarnoleska. Wydawnictwo Literackie.

Ziomek, J. (1960). Wstęp. In J. Ziomek (Ed.), \& J. Kochanowski (Trans.), Psałterz Dawidów. Zakład Narodowy im. Ossolińskich - Wydawnictwo. 